\title{
The end of the Ottoman Empire and the evolution of the Middle East security complex
}

\section{El fin del Imperio Otomano y la evolución del complejo de seguridad de Oriente Medio}

\section{O fim do Império Otomano e a evolução do complexo de segurança do Oriente Médio}

\author{
Jorge M. Lasmar \\ Leonardo C. A. Santa Rita
}

DOI: 10.5752/P.2317-773X.2020v8.n4.p166

Received in: November 10, 2020

Accepted in: January 27, 2020

\begin{abstract}
Since the demise of the Ottoman Empire, the Middle East has undergone several abrupt political changes and became the stage of a series of regional conflicts and disputes by Great Powers that greatly impacted how this regional security complex evolved. Using the theoretical framework of both the School of Copenhagen and the English School, we retrace how these security and insecurity dynamics has been in an unended process of constant evolution since the fall of the Empire and how these processes are embedded in the larger context of systemic great power management.
\end{abstract}

Keywords: Security. Regional Security Complex. Middle East. Ottoman Empire

\section{RESUMEN}

Desde la desaparición del Imperio Otomano, Oriente Medio ha experimentado varios cambios políticos abruptos y se ha convertido en el escenario de una serie de conflictos regionales y disputas de las grandes potencias que impactaron enormemente en la evolución de este complejo de seguridad regional. Utilizando el marco teórico tanto de la Escuela de Copenhague como de la Escuela de Inglés, recordamos cómo estas dinámicas de seguridad e inseguridad han estado en un proceso sin fin de evolución constante desde la caída del Imperio y cómo estos procesos están integrados en el contexto más amplio de sistemas sistémicos. gran gestión de energía.

Palabras clave: Seguridad. Complejo Regional de Seguridad. Oriente Médio. Império Otomano. 


\section{RESUMO}

Desde o fim do Império Otomano, o Oriente Médio passou por várias mudanças políticas abruptas e se tornou o palco de uma série de conflitos regionais e disputas entre as grandes potências que impactaram fortemente a forma como este complexo de segurança regional evoluiu. Usando o arcabouço teórico da Escola de Copenhague e da Escola Inglesa, retraçamos como essas dinâmicas de segurança e insegurança estão em um processo ainda não terminado de constante evolução desde a queda do Império e como esses processos estão inseridos no contexto mais amplo e sistêmico da administração das grandes potências.

Palavras-Chave: Segurança. Complexo de Segurança Regional. Oriente Médio. Império Otomano.

The fall of the Empire: From unity to overlay

The "Sick Man of Europe". That is how Western powers referred to the Ottoman Empire during almost the entire 19th century (CATHERWOOD, 2006). Undoubtedly, this expression is loaded with Eurocentrism and an overt imperialist bias. Nevertheless, it does reflect the Western Europe's prevailing view about the Empire. In fact, it even reflects the view of some within the Empire. Napoleon's conquest of Egypt in 1798 brought out to the Ottoman elite the feeling that there was an increasing chasm between the Empire and the European powers. This feeling could already be felt in several areas ranging from the economic and military passing through the public administration and reaching all the way to state governance. Increasingly, the question of how the Empire should try to implement Western European standards of development dominated much of the internal debates of the Ottoman elites (CATHERWOOD, 2006).

Throughout the 19th century and the first years of the 20th century, the Ottoman Empire equated 'modernization' with 'Westernization'. During this period, the Empire engaged in an attempt of modernization that coexisted with domestic revolutions and crises. In the political and statesmanship sphere, the Empire created new institutions aiming to modernize, westernize and secularize its bureaucracy and public administration. These new organizations intended to substitute the traditional ones with institutions whose practices were closer to the Western European model (ZÜRCHER, 2019). This domestic 'modernization' push was also followed by the adoption of international practices that were aimed at both demonstrating the Empire's acceptance of (European) international society's primary institutions ${ }^{1}$ as well as at constituting evidence of its membership to it. Thus, the Empire also went to great lengths to adapt its diplomatic and international law practices so that they would conform with those norms prevailing within the European international society (IS). In fact, this process - which culminated with the signing of the 1856 Treaty of Paris - was a seen as a necessary condition for the Ottomans to be recognized as legitimate participants in the European concert (PALABIYIK, 2014). In retrospect, the Ottoman Empire’s bid for membership
1. Primary institutions are defined as "relatively fundamental and durable practices that are constitutive of actors and their patterns of activity in relation to each other (BUZAN, 2004b:164). They differ from both 'secondary institutions', i.e. "those referred to by regime theory" (BUZAN, 2004b:166) as well as 'domestic political institutions' which refer to "organizations in a government that create, enforce, and apply laws" (BODDY-EVANS, 2020). For an overview of the evolution of the primary institutions of the Middle East see (BUZAN, GONZALEZ-PELAEZ, 2009). 
2. According to Buzan, "The vanguardist account emphasizes the centrality of Europe in the expansion story and projects a rather one-way view of cultural transmission from the West to the rest of the world" (BUZAN, 2010, p.1).

3. The Young Turks were a Turkish Nationalist group that rose to power in the early 20th century (CATHERWOOD,

2006)

4. Here, once again, the Ottoman Empire equated legitimacy to membership in Western Europe's IS within (Western) IS during its last years illustrate the argument that the expansion of Western IS occurred in a vanguardist ${ }^{2}$ way in which those who were not engulfed by European influence were obliged to make concessions and adapt to the imposed model (BUZAN, 2010).In fact, as Welsh states, it is now clear that "in the early part of the twentieth century, hierarchical practices were evident in the particular ways in which self-determination - the new standard of membership in IS-was applied to the crumbling Ottoman and Austro-Hungarian empires after the conclusion of the First World War" (WELSH, 2017, p.157).

In this context, the Ottoman Empire and its leaders - especially those known as Young Turks ${ }^{3}$ - went to a great extent to modernize their country and to be recognized as a legitimate ${ }^{4}$ force by the European powers. Nevertheless, unlike Japan which was successful in its recognition (albeit with reservations), a series of questionable choices on the part of the Ottomans ultimately contributed to the very fall of the Empire (CATHERWOOD, 2006). An example of such questionable choices was the alliance with Germany in the First World War. However, interestingly enough, the ideas also played a great role in this process. Some of the very Western ideas that the Ottoman reformists endorsed eventually contributed to the dissolution of the Empire. For example, European nationalist-inspired ideals helped to motivate uprisings of local minorities that inevitably led to a weakening of Istanbul's dominance (MATHER, 2014).

After the end of the First World War, and the subsequent dissolution of the Empire, the Ottoman domains that comprised the present states of Israel, Jordan, Syria, Lebanon, Iraq and the Palestinian territories became directly under the control of England and France (CATHERWOOD, 2006). From that moment on, a single empire started a process that eventually gave rise to an entire regional security complex and its sub-complexes. As local leaders of these new territories begun to govern under the tutelage of external powers, the local politics also begun to involve and reflect the larger dynamics of both regional and global disputes between these two powers. The relations between Beirut and Baghdad, for example, were no longer just the straightforward interactions amongst two cities in the same country. At that moment, what was once a centralized unit gave rise to a region marked by the new presence of external political units. However, Middle East (ME) Regional Security Complex (RSC) did not immediately emerge with these changes (BUZAN, WÆVER, 2003).

Buzan and Wæver (2003) define a Regional Security Complex as "a set of units whose major processes of securitization, desecuritization, or both are so interlinked that their security problems cannot reasonably be analyzed or resolved apart from one another" (BUZAN, WEVER, p.44, 2003). Hence, although it is true that the region later became a regional security complex, it did not fulfil the requisite necessary for the demarcation of an RSC straight way. That is to say that the region did not become immediately formed by independent units operating in an anarchic system with durable patterns of amity and enmity and with the material element of the balance of power associated with a geographical 
demarcation. (BUZAN, WÆVER, 2003). At the same time, although one could argue that the region operated as a proxy RSC between France and the United Kingdom, that was not the case. As Buzan and Wæver argue, to "European imperial powers, the world was their region. Under these circumstances of successful global scale imperialism by great powers, the scope for independent regional security dynamics was small" (BUZAN, WÆVER 2003, p.15).

In fact, English and French occupation of the region took place in two ways: via direct domination - as the British mandate from Palestine - and through association with local leaders - such as the Hashemite clan that still holds power in Jordan nowadays (CATHERWOOD, 2006). The presence of these external powers in the region then, made the development of an autonomous RSC impossible. These powers reproduced larger social and political identities at the regional level assimilating much of the then existing local patterns of security. Much of the wider patterns of amity/enmity and balance of power existing between France and the United Kingdom, was transferred to the region assimilating the existing local security dynamics. For example, the interactions between the Hashemites in Jordan and Iraq and the Syrians and Lebanese became directly subordinate to the larger dynamics surrounding the relationship between France and England. Thus, the region transitioned from a centralized political unit to a non-RSC. According to Buzan and Wæver (2003), Non-RSCs exists in two situations. The first are those in which the units are so isolated from each other that their processes of securitization and desecuritization cannot be interconnected. The second, are those cases in which the regional security dynamics is dominated by external powers in what they call overlay (BUZAN, WEVER, 2003). The latter is exactly the case in question.

Surely, it is important to note that France and England did not occupy the entire territory of the ME. Foreign powers did not dominate Saudi Arabia, Iran and the newly born Republic of Turkey. Moreover, Egypt soon achieved its independence in 1922 (CATHERWOOD, 2006). However, at the time, these countries did not immediately evolve into an independent regional security complex. Iran, which was a monarchy at the time, had just emerged from a convoluted domestic crisis that involved revolutions and coups. Additionally, Iran was then strongly influenced by the British who regarded the region as central to the "Great Game"5 of power in the region (KAMRAVA, 2011). The same can be said about Egypt. Even after gaining their official independence in 1922, the Egyptians were still officially tutored by the British on topics such as foreign policy and national defense (CLEVELAND, BURTON, 2009).

In the case of Saudi Arabia, the House of Saud controlled the desert region of Najd, on the Arabian Peninsula. In 1924, Ibn Saud (king of the Saudis) took the position of Hussein (leader of the Hashemite clan) in Hijaz and advanced the construction of modern Saudi Arabia (CLEVELAND, BURTON, 2009). The Saudi consolidation, however, did not bother foreign powers. This is because the kingdom then seemed feeble and the European powers did not have much interest in the remote interior of the desertic Arabian Peninsula. Even so, in a treaty signed in 1927, Ibn
5. The "Great Game" was a period of power dispute between Russian and British Empires in the ME, Central and South Asia (CATHERWOOD, 2006) 
Saud pledged to not threaten the British protectorates in the south of the peninsula (CLEVELAND, BURTON, 2009).

The English and French also were not very concerned with the newly funded Republic of Turkey. Mustafa Kemal, a.k.a. Ataturk, initiated a nationalist movement aimed at creating a Turkish Identity. To this end, he sought to discontinue important institutions of the Ottoman Empire by creating new ‘Turkish’ institutions in its lieu. This process created a complex struggle for autonomy and national unity that resulted in a series of conflicts and millions of lives lost. Thus, under the British and French eyes, Turkey was not a relevant regional player as it was essentially struggling for its own existence (KAMRAVA, 2011).

Hence, the early non-formation of a regional security complex can be related more to European Imperialism (overlay) rather than due to the inexistence of regional disputes and rivalries. But it is necessary to remember that Overlay is not the only mechanism by which the great powers interfere in a region. According to Buzan and Wæver (2003), great powers can also act through penetration which "occurs when outside powers make security alignments with states within an RSC" (BUZAN, WÆVER, p. 46, 2003). According to the authors, penetration is a somewhat "milder" form of external interference in an RSC but that was not what occurred in the ME at the end of the First World War as the European powers presence in the region effectively absorbed and assimilated the logic of the regional balance of power and patterns amity/enmity via direct military occupation and practices of colonialism.

However, although the presence of France and England in the ME during the inter-war period was marked by overlay, it was also responsible for the beginning of the creation of new patterns of amity/enmity that would deeply affect the region today. British and French colonialism left indelible marks that deeply affected the pattern of social organization in the ME and the way regional actors related to each other. The somewhat abrupt departure of the European powers in the region also not only caused new actors to emerge but also created a dispute to grab the power and space left by the colonizers that became one the main drivers of the regional security architecture in the immediate post-World War II period. (CATHERWOOD, 2006).

An example of this process can be seen in how some countries in the region organized they newly independent countries. Countries such as Jordan, Iraq until 1958, Egypt until 1952, and the small countries of the British protectorates in the Persian Gulf, all became monarchies due to the direct influence of the British. In addition to the fact that England is also a monarchy, it also used its relations with local dynasties as an intermediate element of its realm as a way to guarantee the continuity of its (indirect) authority over the region while at the same time guaranteeing a certain level of legitimacy (CLEVELAND, BURTON, 2009). This British modus operandi allowed the power transition to be much more obvious in its former domains since the new leaders were in collaboration with the British (KAMRAVA, 2011).

In what regards the French domains - such as the current Lebanon and Syria - the situation has evolved differently. Because France is a 
country with a long republican tradition, it did not seek to associate itself with monarchic dynasties. Thus, it pulverized its relations with various local leaders and exercised a stronger direct presence. (KAMRAVA, 2011). This French modus operandi produced two important legacies for the region: The first of them is that both Syria and Lebanon evolved into republican regimes when they gained independence. The second legacy, on the other hand, is related to the fact that, as a result of spreading local leaderships and exercising a more direct dominance in the region, France hampered the political transition in Syria and Lebanon and fostered some conflicts that had lasting consequences for the regional security architecture. (KAMRAVA, 2011).

Another important legacy of the European presence in the ME, and perhaps the most striking, is the issue of Palestine. Despite the enormous discussions about the origin of the conflict, the fundamental role that the British played in its emergence is undeniable (CATHERWOOD, 2006; SINGH, 2011). The English mandate in Palestine had a different type of organization because, instead of allying themselves with a single local leadership, the British preferred to exercise direct domination in the region progressively formulating policies that prevented the concentration of forces with an Arab leadership. This was one of the main contributing factors that subsequently prevented the emergence of cohesion amongst local Arab forces during the war against the Zionists in 1948. (KHALID, 2008).

The British are also responsible for the emergence of the conflict not only due to the policies deliberately adopted but also for negligence. During their mandate in Palestine, the British allowed, in what appears to be tacit support for the Zionist interpretation of the Balfour Declaration, the migration of thousands of Jewish to Palestinian territory, increasing social tension in the region (CATHERWOOD, 2006). The British were also negligent in their process of leaving the region. By not establishing any transitional governmental mechanisms, the British allowed the subsequent power struggle to develop in a very violent way (CATHERWOOD, 2006). This stance from England allowed for the European Jewish issue to be exported to Palestine and become one of the main elements that would dictate the ME's social dynamics of amity/enmity in the future.

Hence, the troubled evolution of the ME non-Regional Security Complex shortly after the fall of the Ottoman Empire set the tone for what was to come. From a centralized unit (Ottoman Empire) to an overlay RSC, what was seen in the ME was an abrupt transition of power and a complete rearrangement of regional forces. However, although it overcame purely regional security dynamics, foreign occupation in the ME served as an incubator for new power relations and the re-arrangement of the regional structure of amity/enmity.

Post-World War II

The period immediately after the Second World War was marked by the end of the overlay in the ME and the beginning of the formation of an RSC with its own dynamics. The Israel/Palestine issue, the element of 
8. In summation, macrosecuritization is a major securitization process that absorbs all others (BUZAN, WEEVER, WILDE, 1997).
Arab nationalism and Pan-Arabism, as well as the relationship between Islamism and politics were the main essentially regional elements that contributed to the re-design of the power relations and the patterns of amity/enmity in the ME. However, the elements of macrosecuritization ${ }^{8}$ of the Cold War did not allow the evolution of a standard RSC. The whole security issue in the $\mathrm{ME}$, as well as practically all over the world, was absorbed by the power struggle between the US and the USSR. The ensuing regional security complex, therefore, was an RSC centralized by foreign powers, in which the global disputes between the US and the USSR dominated much of the regional social dynamics. However, the local patterns of securitization and desecuritization were sufficiently interconnected to configure an RSC in its own (BUZAN, WÆVER, 2003). According to Buzan and Wæver (2003), an RSC is centralized:

\begin{abstract}
Because the core actor is globally orientated, the security dynamics of the region are hugely distorted and suppressed. But since all other actors in the region have their concerns linked to each other, a general map of global security would still show a clear regional formation of densely knit connections compared to a lack of connections in and out of the region for most units. This therefore can still be treated as an RSC (BUZAN, WÆVER, p. 56, 2003)
\end{abstract}

One of the main security issues in the ME since the end of the Ottoman Empire is, of course, the conflict between Israelis and Palestinians. Since the departure of the British from the region, a series of conflicts have emerged, the most obvious culminating in the creation of the state of Israel in 1948. These conflicts were marked by the organization of the Zionist forces in contrast to the disorganization of the local Arab forces, by the massive expulsion of the Arab populations from territories occupied in 1948, by the not-so-obvious support that the Zionists received, and by the power struggles between the Arab nations involved in the conflict (ROGAN, SHLAIM, 2008).

This initial support received by the Zionists was not necessarily obvious as it was quite different from that which followed throughout the Cold War. Most of the armaments and military equipment that the Israeli used in the 1948 war originated in the European socialist bloc. Countries like Czechoslovakia, Poland, and even the Soviet Union sent many weapons to Zionists to fight the Palestinians and found the state of Israel (SHLAIM, 2008). This support, however, would not last long as power struggles, both regional and systemic, would lead to rearrangements in alliances across the ME.

Another important aspect of the 1948 war, which is fundamental to understanding the evolution of RSC in the ME, was the power relationship between the other Arab countries during the conflict. On one side, there was the pro-Hashemite bloc, headed by the kingdoms of Jordan and Iraq, and whose geopolitical objective was the creation of an "Arab Kingdom" as had been promised to them by the British in return for their support in organizing a revolt against the Ottoman Empire and which would encompass much of the Levant, including the territory of Palestine. On the other side, there was the anti-Hashemite bloc, led by Egypt, Saudi Arabia and Syria, whose objective was precisely to prevent the plans of the clan led by the king of Hashemite Jordan to materialize 
(SHLAIM, 2008). These geopolitical movements of Arab leaders in the ME demonstrate that the overlay no longer existed in the post-Mandate period and that local forces were already re-shaping the dynamics of the regional security and insecurity structure.

The conflict between Israelis and Palestinians has had a significant role in this process of re-shaping the security and insecurity structure of the ME. Two specific events that marked this conflict demonstrate the influence of the Cold War dynamics in the Region: the 6 Days War and the Yom Kippur War. These two important conflicts clearly demonstrate how regional interests and disputes - especially in Nasserist Egypt and in the preemptive stance of the State of Israel - reflect the broader systemic dispute between the US and the Soviet Union and how it manifested itself in the ME (CLEVELAND, BURTON, 2009). In summation, during the 1967 Six-Day War, a coalition of Arab states led by Egypt initiated some provocative moves towards Israel which, in turn, responded quickly with a preemptive attack, bringing the war to a quick end. The result was terrible for the Arabs and even more so for the Palestinians. The Israelis, in addition to imposing a significant military defeat on the Arabs, also managed to annex the territories of the West Bank, the Golan Heights, the Gaza Strip, and the Sinai Peninsula (MASSOULIÉ, 1996). The 1973 Yom Kippur War can be considered a direct consequence of the events of June 1967. Only this time the Arabs attacked first and took the Israelis by surprise. Hostilities ended only with direct intervention of the two superpowers and the underlining threat that there was a real possibility that the conflict would escalate to a global, even to nuclear, war (MASSOULIÉ, 1996).

In both conflicts, it is possible to observe how the areas of influence of the US and the USSR in the ME were sewn together and how the regional disputes were quickly assimilated by the Cold War logic. The Arabs, mainly Egypt, Syria, and republican Iraq, were massively supported by the Soviet Union. The USSR, in turn, was interested in increasing its sphere of influence in the ME especially in the Mediterranean. The United States, in turn, has been traditionally closer to the monarchies and Turks (who are members of NATO) as well as greatly aligned with the state of Israel as a form to contain Soviet interests in the region (CLEVELAND, BURTON, 2009). Thus, the patterns of amity and enmity and the dynamics of the regional balance of power were clearly penetrated and centralized by systemic disputes. The rivalry between Arabs and Israelis was embedded within the larger context of the macrosecuritization of the ideological and material disputes between "Western Imperialism" and "Communist Tyranny".

The ideological component of the Cold War draws attention for another important ideational ingredient of the securitization processes in the ME: Arab Nationalism/Socialism. This ideological component has had an important relationship with both the Cold War dynamics as well as with the bid for membership in IS by the recently independent/autonomous states. Abdel Nasser's Egypt had an important role in the development and dissemination of the Arab Nationalism ideology. This ideology included principles such as the need for a strong state, militarism, 
7. A state retrospectively known as North Yemen that existed between 1918 and 1962 in the northern part of current secularism (though not atheism), anti-imperialism and Pan-Arabism (CLEVELAND, BURTON, 2009). The formers help explain the influences of external ideologies and ideas in the region, while the latter is crucial to understand why and how the regional patterns of amity and enmity evolved as they did.

The Arab Nationalism/Socialism was thus a very important component in the construction of the Middle Eastern alliances and an important driver of the alliances and alignments that took place on second half of the 20th century. Since Nasser came to power in Egypt, a division in the ME between conservative monarchic forces and progressive republican forces began to be drawn. Traditionalist forces were represented mainly by the Hashemite kingdoms of Jordan and Iraq (until 1958), Saudi Arabia and Iran (until 1979). "Progressive" forces, on the other hand, were initially represented by the republics of Egypt and Syria. Iraq also joined this group in 1958 after it underwent a republican military coup. This coup, and the subsequent change in Iraq's alignment, became worrisome to the monarchical leaders of the ME who feared that republican, secular, military and progressive movements could spread within their territory and threat their monarchic social order (HALLIDAY, 2005).

Another element of concern for conservative countries in the region was Nasserist Pan-Arabism. Nasser and the republican forces of the ME, especially Syria, came to defend the unity of the Arab peoples under a state which would be built based on the principles of Arab Nationalism/Socialism. In 1958, Egypt and Syria created the United Arab Republic (UAR) which intended to encompass all Arab states under Egyptian leadership. However, due to issues such as the centralization of power in Cairo as well as the non-accession of other countries, the UAR was shortlived and ended in 1961 (ROMERO, 2015). This clash of ideas led to actual conflicts. An example was the conflict in Yemen in the 1960s. Egypt, which supported the formation of a republican government in North, suffered heavy casualties in the conflict. Meanwhile, Jordan, Saudi Arabia, Iran and even Israel supported the royalists who fought to preserve the local Mutawakkilite Kingdom ${ }^{7}$ (HALLIDAY, 2005).

Thus, one can establish a direct relationship between the movement of Arab Nationalism/Socialism and several impacts of the Cold War over the dynamics of the region. In fact, Fred Halliday (2005) states that Nasser's rise in Egypt and his ideology was what brought the Cold War to the region:

The revolution of 1952 was to unleash a process of radicalisation that profoundly affected Egypt as well as the Arab world. It brought the Cold War to the Arab world, or, perhaps more accurately, allowed the Cold War to come to the Arab world, aligning Arab states with one or other bloc in the Cold War itself, and dividing Arab states themselves along Cold War lines. It also provided a new ideological context for the rising tide of popular, if also conspiratorial, pressure (from within the state and from outside) on states (HALLIDAY, p. 112, 2005).

As a matter of fact, the Nasser Pan-Arabism movement was strongly built-in opposition to the Baghdad Pact. This agreement was spearheaded by the United States and aimed primarily at containing the interests of 
the Soviet Union in the ME (HALLIDAY, 2005). Thus, the movement led by Nasser brought another ideational element to the Cold War regional dynamics: that of socialism. Local leaders, especially in Egypt and Syria, evoked the need to create a socialism with "Arab characteristics" and to adapt it to the political and social regional context. This Arab socialism retained some differences with the Soviet model but did advocated some shared principles such as state-driven economics, aversion to financial capital, militarism, nationalism and anti-imperialism (CLEVELAND, BURTON, 2009). Once again, local patterns of amity and enmity are being centralized and penetrate by the logic of systemic dispute.

This model of Arab Nationalism/Socialism lost its strength by the mid-1970s. Facts such as the death of Nasser, the normalization of relations between Egypt and Israel and the subsequent rapprochement between Cairo and the West, especially in economic matters, contributed to such waning (MASSOULIÉ, 1996). Nevertheless, Arab Nationalism/ Socialism acquired a new form in Iraq and Syria with the rise of the Ba'ath party. In Damascus, the Assad family came to power, while in Baghdad the military leader Saddam Hussein commanded the country. Despite the weakening of the Pan-Arabism, some of its ideas such as socialism, nationalism and anti-imperialism remained. So did the relationship with the USSR (HALLIDAY, 2005). Indeed, it was during this period that the Soviet Union built aerial and naval bases in Syrian territory (ALLISON, 2013).

The expansion of the Arab Nationalism/Socialism ideology is also an important reflection of the broader issues surrounding the expansion of the European IS and the bid of young Middle Eastern countries for its membership. This ideological set of ideas departed from Nasser and reached from Saddam Hussein to Bashar al-Assad in their respective attempts to adapt their regional and domestic political institutions to comply with the Western norms and institutions. The central role that norms and ideas such as secularism and nationalism had within this ideology are an indicative of such attempt. However, the bid for membership in Western IS was fraught with tensions. The actions and ideas adopted by the Middle Eastern states during this period exposed the deep tensions, limitations and contradictions that exist in interstate society. Local ideas and movements marked by exacerbated nationalism, anti-imperialism and the pan-Arabism ideology can also be seen as a reaction to both the vanguardist expansion of Western IS as well as the inequalities inherent to its membership. The ME bid for membership took place during what can be termed the third phase of the Western society expansion. This phase marks the accession of ex-colonies as members of Western IS. However, while tensions, limitations and contradictions are inherent to all normative structures (SANDHOLTZ, 2007:13), there was a significant degree of normative tension between the regional social structure in formation and the existing Western values and norms. This normative misalignment created a normative sensitivity that left the regional IS especially prone to instabilities. This is because the high degree of functional and normative tension created between the forming regional institution and the broader imposition of an uneven Western social structure. These tensions and 
contradictions reflect the misalignment of the regional norms and values with the perceived Western social reality. In other words, the vanguardist expansion of Western values and norms were not fully aligned with new forming regional collective representations and expectations. Thus, this led to a prolonged legacy of domination and cultural differences that would generate long lasting instability. In fact, according to Buzan:

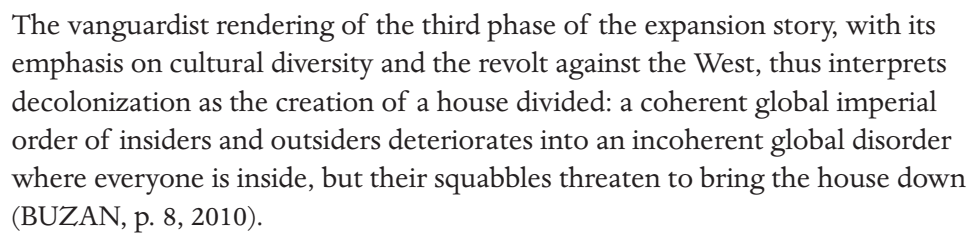

However, it is important to note that not all countries adopted the ideas and values of the pan-Arabism movement nor those who did adopted it to the same degree. Turkey and Iran, for example, were neither deeply involved in the conflicts between Israelis and Arabs nor greatly aligned with Arab nationalism/socialism. During much of the Cold War, Turkey looked much more to the West rather than to the East and thus became directly drawn into the global conflict. Turkey's strategic location made the country a key part of NATO's strategy to contain the USSR (LIKA, 2015; OUTZEN, 2012).

Iran, ruled by Shah Reza Pahlavi, was also an important ally of the United States and the United Kingdom in their efforts of containing Soviet interests in the region. However, due to the 1979 revolution, the authoritarian regime of Pahlavi was overthrown by an Islamic popular revolution led by Ayatollah Khomeini. Khomeini would become supreme leader of the Islamic Republic of Iran and foster the question of political Islam and religious fundamentalism (KAMRAVA, 2011). But the question of political Islam and religious fundamentalism would not be restricted to the Iranian revolution alone. In the last years of the Cold War, the issue became central in the securitization and desecuritization processes of the ME. The emergence of jihadist movements, the rise of groups such as Hezbollah and Hamas as well as the consolidation of the Saudi kingdom as a regional power brought the ideas of radical political Islam to the very center of the security debates in the region. The consolidation of the United States as the only superpower after the fall of the USSR and later the advent of the Global War on Terror, would further intensify the decisive role of radical political Islam in the construction of ME's amity and enmity architecture and security dynamics.

From the end of the Cold War to the War on Terror

From the 1980s onwards there was a visible decline in the geopolitical power of the Soviet Union. This decline culminated with the country's official dissolution in 1991. From that point on, while the United States became the only acting superpower, the Cold War bipolar rivalry lost momentum in the ME as it did everywhere else. But the end of the Cold War did not represent the end of the presence of external powers in the Region. The US became the only external centralizing power in the 
region. Issues such as the war between Iran and Iraq, the invasion of Iraq by Kuwait, the rise of radical extremist groups, the US invasion of Iraq and the geopolitical dispute between Saudis and Iranians were all directly or indirectly influenced by US' foreign policies. Consequently, during the post-Cold War period, new patterns of amity and enmity and a new regional dynamic of balance of power emerged in the ME. Both, all of which were 'centralized' by the United States.

The war between Iran and Iraq was a milestone in this reshaping of the internal security dynamics in the ME and its centralization. At the time, the Iranian revolution encouraged local forces to also overthrow their respective leaders. At the same time, Saddam Hussein wished for an opportunity to consolidate his power in Iraq and the region as the main Arab leadership. (KAMRAVA, 2011). The dreadful war lasted from 1980 to 1988 and did not result in change in the status quo. However, the war consolidated some changes in the regional institutional design: Firstly, the US became the main power in the region; Secondly, Iran would become central to the regional balance of power and patterns of amity and enmity; Thirdly, Islam - and especially political Islam - would become a crucial ideational element in the construction of the regional processes of securitization and desecuritization.

The end of the war between Iran and Iraq happened simultaneously with the end of the Cold War. This is an important context because the following decade, the 1990s, seemed to signal a broader transition to a liberal democratic and capitalist world order marked by the consolidation and expansion of the liberal order in Western IS. This transition briefly seemed to consolidate a social structure informed by principles of cooperation, liberal peace and multilateralism. However, what followed was the beginning of a process a re-negotiation of the identities and roles of the great powers in the post- Cold War world undertaken directly through their interaction and which is yet to attain its final form.

In this process of re-negotiation, one of the first key events that marked this new moment in global geopolitics - and which directly concerns the ME - was the first Iraq intervention. Iraq, motivated by various causes such as outstanding debts from the Iran war, Saddam Hussein's private interests as well as geopolitical objectives, decided to invade $\mathrm{Ku}-$ wait. The international response came quickly through a US-led coalition that quickly drove Iraqi forces out of Kuwait with the United Nations' Security Council's approval. The conflict demonstrated not only that the end of the Cold War did not undermined US' position as the sole superpower capable of projecting military force anywhere in the world but also that the World had deeply changed, and its diplomatic actions were no longer restricted by soviet rivalry. However, this episode marks yet another deeper change.

The end of the Cold War brought about a radical process of change in existing social and power structures resulting in a significant transformation of interstate society. As a result, the bipolar power structure prevalent during the Cold War shifted towards a more fragmented, hierarchical, multi-layered and unipolar one. Simultaneously, both the ideological rivalry between the superpowers and the long-standing threat of nuclear 
8. Note, however, that the Security Council has been very wary of declaring a war as being a case of "aggression", even when it is explicitly so. annihilation were de-macrosecuritized (at least as a matter of public concern) (BUZAN; WÆVER, 2009, pp. 270-271). Simultaneously, the Western liberal economy with its logic of interdependency steadily expanded to cover most of the globe. Although it appears, at first glance, that the consolidation of a social structure of friends/rivals and the liberal order would lead to a further narrowing of the legitimate uses of war and therefore its eventual obsolescence, in fact, these changes created conditions for a transformation in the uses of war. In other words, the consolidation of the liberal order transformed (rather than reducing or eliminating) the legitimate and socially accepted uses of war.

The reaction of the UN's Security Council to the Iraqi military invasion of Kuwait in 1990 was central to this trend. The post-Cold War attempts to criminalize wars of aggression and reject the use of war for territorial gains have intensified. Coming immediately in the wake of the Cold War and when interstate society was experiencing a moment of great normative uncertainty, SC's reaction to the invasion clearly delineated that wars of aggression fought for territorial gains were not only unacceptable but also that it was willing to use military force against the aggressor state in order to enforce compliance. Hence, the SC was able to reach a consensus in condemning this particular use of war as markedly illegitimate in the post-Cold War era. To provide some details: the SC resolutions not only authorized the collective use of military force against Iraq, but it also explicitly condemned the use of military force for territorial gains (UNSC, Res. 662); stated that the state of Iraq was legally liable to pay for the damages caused by its acts (UNSC, Res. 674, Res. 687) and also stated that Iraq would need to compensate Kuwait for its illegal actions (UNSC, Res. 692). The institutional enforcement of these resolutions clearly demonstrated the shift that had occurred in interstate society, which unlike a century ago, now no longer accepted territorial wars of aggression as either legitimate or socially acceptable.

The post-Cold War narrowing of the institution of war was not only the result of a historical process limiting the legitimate uses of war but also embedded in the growth of the liberal economy as well as in the broader transformations of the international environment. Taken collectively, these transformations have impacted existing technologies of interaction of states by not only increasing the overall density of interactions amongst them but also by diversifying these patterns of interaction. Thus, both the Iraq intervention and these broader changes in global order clearly impacted both MENA's regional dynamics as well as the United States' presence there.

The 1991 Gulf War resulted in an increasingly fragile and isolated Iraq followed by an increasingly regionally engaged US. Relations between Baghdad and Washington deteriorate so badly that in 2003 the United States decided to intervene in Iraq a second time on the grounds that Saddam Hussein's government was developing weapons of mass destruction. Unlike in 1991, the intervention did not obtain the UN Security Council's approval. Along with the invasion, the US advocated a regime change that actually meant the transformation of the regional international institutions towards ones more aligned with the US' project of con- 
solidating a broader 'new' post-Cold War liberal 'global' order. In its Iraq's discourse, the US clearly emphasized the importance of replacing local institutions with liberal and democratic ones. This narrative was lined up with its broader bid for the re-negotiating its identity and role in the postCold War world and became known as Liberal Hegemony. ${ }^{9}$ This narrative was followed by concrete actions that significantly impacted the RSC of the ME transforming both the regional patterns of amity and enmity as well the local balance of power as one of the main regional military powers crumbled into a failed state (KAMRAVA, 2011).

This process of transformation was immediately felt in the tense relations between Saudi Arabia and Iran. With the consolidation of Iran's regime and Saudi Arabia's economic growth since the Oil Crisis, both countries have been increasingly consolidating as regional poles of power. This process of redefining the regional balance of power became accelerated especially after the 2003 intervention in Iraq seemed to have removed the latter from the equation. It also compounded their rivalry as both competes for political influence in the ME portraying diametrically opposed views about the United States, Islam and regional politics.

In order to project its power and influence in the region, Iran acts heavily through proxy non-state actors. Tehran's relationship with each of these groups varies in the depth and objectives (IISS, 2019):
9. The 1990s are also known as the period of Liberal Hegemony, in which the United States engaged in defending its ideas and interests and consolidating itself with the Cold War's winning power. According to Mearsheimer (2018) "Liberal Hegemony is an ambitious strategy in which a state aims to turn as many countries as possible into liberal democracies like itself while also promoting an open international economy and building international institutions" (MEARSHEIMER, p.8, 2018)

\section{Image 1 - Iran and its regional partnerships}

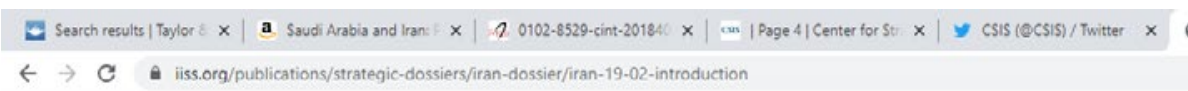

(5) Iran's Networks of Influ $x+$

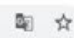

the likely durability and future course of their relationships with Iran.

\begin{tabular}{|c|c|c|c|c|c|}
\hline & Partner & Strategic ally & Ideological ally & Proxy & State organ \\
\hline $\begin{array}{l}\text { Key } \\
\text { criterion }\end{array}$ & $\begin{array}{l}\text { The client pursues } \\
\text { its relationship } \\
\text { with the patron } \\
\text { due only to political } \\
\text { or transactional } \\
\text { expediency, and } \\
\text { may or may not } \\
\text { continue to pursue } \\
\text { objectives in } \\
\text { common with the } \\
\text { patron absent its } \\
\text { support }\end{array}$ & $\begin{array}{l}\text { Without the } \\
\text { patron's support, } \\
\text { the client would } \\
\text { continue to pursue } \\
\text { objectives in } \\
\text { common with the } \\
\text { patron based on } \\
\text { strategic } \\
\text { convergence, albeit } \\
\text { with more limited } \\
\text { resources }\end{array}$ & $\begin{array}{l}\text { Without the } \\
\text { patron's support, } \\
\text { the client would } \\
\text { continue to pursue } \\
\text { objectives in } \\
\text { common with the } \\
\text { patron owing to } \\
\text { their ideological } \\
\text { affinity, albeit with } \\
\text { more limited } \\
\text { resources }\end{array}$ & $\begin{array}{l}\text { Without the } \\
\text { patron's support, } \\
\text { the client would } \\
\text { continue to hold } \\
\text { objectives in } \\
\text { common with the } \\
\text { patron (owing to } \\
\text { either common } \\
\text { ideology or } \\
\text { expedient } \\
\text { Interests) but be } \\
\text { unable to pursue } \\
\text { them }\end{array}$ & $\begin{array}{l}\text { Without the } \\
\text { patron's } \\
\text { support, the } \\
\text { client would } \\
\text { cease to } \\
\text { exist }\end{array}$ \\
\hline Example(s) & Hamas & $\begin{array}{l}\text { Houthi movement } \\
\text { (Ansarullah) }\end{array}$ & Hizbullah & $\begin{array}{l}\text { Syrian National } \\
\text { Defence Force }\end{array}$ & $\begin{array}{l}\text { Liwa } \\
\text { Fatemiyoun; } \\
\text { Liwa } \\
\text { Zalnablyoun }\end{array}$ \\
\hline
\end{tabular}

Source: IISS. Iran's Networks of Influence in the Middle East. International Institute of Strategic Studies. 2019

As an example of this modus operandi, Iran has also steadily grown its influence and presence in Iraq by providing direct support to selected Shiite militias in the country such as Asaib Ahl al-Haq and the Badr Or- 
10. The third being Jerusalem/Al-Quds (Al Aqsa Mosque). ganization. However, here again we can identify US' attempts to counter Iran and centralize the regional dynamics. One such attempt was the US attack that killed the Iranian General Qassem Suleimani. He was the commander of the Quds forces, an arm of the Iranian Revolutionary Guard dedicated precisely to support pro-Iran groups outside Iran (IISS, 2019).

Saudi Arabia, in its lieu, seek to project their regional leadership in both the sectarian/religious and the political/material arenas. With regard to the sectarian aspect, Saudi Arabia finances groups (armed or not) and educational institutions that corroborate its official interpretation of Islam (TZEMPRIM et al. 2015). They also claim leadership as the guardians of two of the three ${ }^{10}$ most sacred sites for Islam, namely Mecca and Medina. This discourse is used to capitalize the image of the Kingdom as the Protector of the Faith (CERIOLI, 2018). Materially, the House of Saud projects its influences by providing military and political support to conservative governments aligned with the Riyadh policy, although they do not necessarily demand and ideological alignment with the regime as is the case with Yemen (ARRAF, 2017).

Thus, the Saudi Iranian relationships constructs a complex set of direct and indirect interactions in the ME which, in turn, constructs much of the regional dynamics, social structure and balance of power. This strong pattern of rivalry and enmity substantially carves much of the regional security complex attributes. Yet, another important element also permeates and shape these dynamics: The United States' presence. Washington sees the Saudis as one its main allies in the region with a shared common interest in containing Iranian influence. The US and Saudi Arabia have, thus, became somewhat mutually dependent. On the one hand, the US provides political and military support for Riyadh. On the other, the Ibn Saud family works to ensure the stability of the oil markets and permits that the US uses its territory to project its military power in the region (CERIOLI, 2018).

This US centralization in the ME RSC can also be observed in the Israeli Palestine issue on many occasions such as in the key role the US had in the Oslo Accords (KAMRAVA, 2011) or more recently in the Peace to Prosperity proposal made by the Donald Trump administration (WHITE HOUSE, 2020). The United States engaged as a key player in the implementation of both agreements with a clear message: If the conflict between Israel and Palestine has a solution, that solution requires Washington's consent. Thus, although Buzan and Wæver (2003) consider the ME Regional Security Complex as standard due to its own internal dynamics and characteristics, we argue that the macrosecuritization of the Cold War, followed by the central role the ME still has in the US's bid for a new understanding of unipolarity, though do not eliminate the regional security dynamics are enough to distort, suppress and, ultimately, centralize them.

Thus, it is important to understand the ME RSC within the broader global game. The US presence and actions in the ME impacts the broader post-Cold War international environment by functioning as a policy of normative organization. The behavior adopted by the world's sole superpower in the region is not a novelty, but it does propel both the consoli- 
dation of new identities and the institutionalization of new roles within interstate society. By undertaking offshore military operations in the region, the US amplifies the political and military gap between states and also compounds the existing hierarchy in interstate society. Nevertheless, the behavior of the sole superpower and the disagreements generated by it also demonstrate that the collective identities that it is attempting to construct are thus far shallowly internalized and therefore unstable (LASMAR, 2015). All this then serves to generate an environment of uncertainty and instability and seems to indicate that the end of the Cold War brought about a re-negotiation of the meaning of great power management that will only acquire a more permanent form if, and when, the US actions become socially perceived as symbolizing the new de facto meaning of unipolarity.

Washington's discourse to the region inextricably associates the US position as the sole superpower with its unique capability to employ material and human resources to manage the security threats in the region. Under the banner of its actions in the region, the US constructs a new component in the identity of a superpower whereby the position of a superpower is dependent, amongst other things, upon the capacity to address offshore threats. The US centralization of the ME, therefore, ultimately impacts the norms of great power management by creating a series of additional criteria that must be met before a state can be recognized as a superpower within interstate society. Thus, the interaction amongst great powers since the end of the Cold War represents a re-negotiation of their identities and roles in the post- Cold War world and their roles in the ME RSC play a key role in that game. However, this process of re-negotiation has yet to attain its final form. Recent changes in the Chinese and Russia attitude towards both IS and the region demonstrate that they also intend to offer alternative and revisionist views of what is the new de facto meaning of the current international system's polarity. Similarly, at a regional level, Turkey and Qatar also have increasingly adopted revisionist policies intended to advance their own alternative views for what is the current meaning of the regional balance of power and security dynamics.

Present and Future

In this context, recent episodes have demonstrated that there is a mounting pressure for normative changes from both within and outside the ME RSC. Turkey is becoming increasingly involved in regional conflicts and clamming its role as a regional leader. Erdogan turned its backs to the European Union and militarily intervened in both the Syrian Civil War (MASCITELLI, 2019) and in the Nagorno-Karabakh conflict. On the ideational front, it is clear that Turkey is also trying to rebuild the country's image and legacy as the bedrock of Islam. The recent decision made by the President to reopen Hagia Sophia as a mosque and not as a historical museum is one of the biggest examples that Turkey is distancing itself from secularism and clamming its position in Islam and in the ME (DANFORTH, 2020). 
Another important regional force affecting the amity/enmity dynamics in the ME is that of the State of Qatar. As other Persian Gulf States, Qatar is known as an absolute monarchy as well as a rich oil and gas exporter. However, the Qatari power goes beyond the energy markets as the country has strong soft power capabilities. Qatar controls the greatest media center in the region and use sports, particularly football, as a tool to improve the country's image and exercise influence over its neighbors (FAHY, 2018). Qatar has sought to reaffirm its political independence and have established connections with Islamist groups and dissenting individuals across the region (FAHY, 2018). As a result, since 2017 Qatar is isolated in the region as other Middle Eastern countries accuse Doha of using Al-Jazeera to manipulate other countries' domestic environment and of supporting extremist groups such as Muslim Brotherhood, Hezbollah, and even al-Qaeda and ISIS (IISS, 2019).

The adoption of a more revisionist behavior by Russia and China also added significant outside pressure to re-shape the regional amity/enmity dynamics. Since the Civil War had erupted in Syria in 2011, Russia overtly increased its military presence in ME to unprecedented levels in the post-Cold War era. Beyond Kremlin's intentions to preserve its positions in Eastern Mediterranean, the Russians supported the Bashar al-Asad regime and the maintenance of the Syrian status quo. This move was intended to directly oppose the U.S support of rebel groups and the Washington's intentions of regime change (PEIPER, 2019). But, most importantly, is was also directly intended to counter the broader US post-Cold War bid for a specific meaning of unipolarity. And this was not an isolated action. Russia sees the broader ME - and, more specifically, US deep interests and involvement in the region - as an important arena to counter Washington's bid. For example, Russian Russia is also one of the biggest supporters of Iran using a myriad of economic tools to overcome the U.S sanctions against the Persian country (KHLEBNIKOV, 2019). Russia's participation in the Syrian Civil War and its support for Iran undoubtedly reveals the Kremlin's revisionist intentions against both the consolidation of a U.S backed Western order as well as US' centralization of the ME. Thus, Russia has been taking a vanguardist reaction against the pressure exerted by Western international order over traditional non-liberal regimes (BUZAN, 2010) and the $\mathrm{ME}$ is at the center stage of such reactions.

Another great power that is increasingly - though discreetly turning its attention to the ME is China. China official discourse is that of non-alliance, non-interference, and of never seeking a global hegemony. Thus, it does not act in the regional the same way as the Russians or Americas. Nevertheless, the Chinese are steadily expanding their presence in the region (CHINA, 2019). China sees the region as key to sustain its growth as it needs enormous quantities of oil coming from the ME to keep its economy flowing. Due to the region's instability, the People's Liberation Army Navy (PLAN) established its first overseas base in Djibouti to protect Chinese interest in the Gulf of Aden (LIN, 2019). The $\mathrm{ME}$ is also extremely strategically important for China as it is in the core of China's Belt and Road Initiative (GORDON, TONG, ANDERSON, 
2020). Thus, China has been clearly signaling the intention of increasing its presence in the region. Additionally, China shares with Russia the opposition over both the Western liberal order as well as the US' bid to consolidate its particular understandings regarding the system polarity and the primary institutions of IS. China thus has been seeking to establish relations in the region without questioning the countries' domestic regimes and advocating its status and role as a great power (CHARAP, DRENNAN, NOËL, 2017).

Questions about the recent policies of the United States towards the region as well as the possible shifts that the Biden election might bring about to these policies are also one of the possible big game-changers in the ME's RSC. Since the beginning of the events of Arab Spring, the U.S policies towards the region have been received with suspicion by Middle Eastern countries as well as seen as marking the US as an unreliable partner. Episodes such as the lack of help to the Mubarak's regime in Egypt (PINTO, 2012) or the troop withdrawal within Iraqi and Syrian Kurd territories have greatly added to a steady erosion of US' leadership in the region. Another controversial decision was to unilaterally withdraw from the nuclear treaty with Iran. Undoubtedly, these set of decisions undermined the US position in the ME RSC (EWERS, 2019) greatly contributing to the possibility of the erosion of its centralization and opening space for a deep re-shaping of its regional dynamics of security and insecurity.

Conclusion

The end of the Ottoman Empire caused an abrupt transition in the ME. What was once a centralized and somewhat coherent unit fragmented into several new units that were immediately overlayed. In the postWorld War II era, the region begun a process of forming an autonomous RSC but it became centralized and caught by the Cold War macrosecuritization. With the demise of the Soviet Union, the ME RSC continued to evolve in its own dynamics but was still largely influenced by the remaining superpower.

Thus, in a nutshell, since the fragmentation of the Ottoman Empire, security issues in the ME region have evolved, to a large extent, influenced by the constant presence of great and superpowers in the local Regional Security Complex. This is not to say that the regional dynamics of the balance of power and the patterns of amity and enmity have not evolved. The ME RSC has had a series of securitization and de-securitization processes sufficiently interconnected by regional actors. Nevertheless, these processes were, at some point, overlayed - as in the case of the British and French occupation - suppressed - as it happened due to the dynamics of the Cold War - distorted - as it happened and still happening due to the US presence in the region.

Thus, to understand the dynamics of regional security is important to understand the role of outside powers in the ME. This is because these external great and superpower have displayed a vanguardist foreign policy towards the region that reflects broader geopolitical games. The advance of Western society towards the ME in the last days of the Ottoman 
11. Includes Jordan and the former kingdom of Iraq.

12. Includes all the monarchies from Arabian Peninsula.

13.Arab countries lead by Nasser's Egypt.

14. Includes all the monarchies from Arabian Peninsula (except for Qatar) and
Empire and after its fall also introduced the newly formed countries of the region as members of a Western IS. Thus, at the same time, Western values and institutions were imposed on a cultural context that had distinct values and norms. The consequence was a formation of a complex, constantly evolving regional security complex.

Finally, the ME is currently undergoing yet another process of normative change and re-shaping of its dynamics of security and insecurity. The recent events bring about important questions about the future of the ME RSC. Will Russia's and China's presence in Syria extend over time? How it will impact the regional dynamics? How have China's interests penetrated the ME? How could an eventual decrease in the US leadership affect the RSC? How would the regional balance of power and patterns of amity and enmity be affected in the event of Iran and/or Saudi Arabia's nuclearization? What role is Turkey to play in this re-negotiation of the regional dynamics? These are all open questions that will guide future debates on the complexities of the ME RSC.

Appendix: Summary of Middle East patterns of amity/enmity throughout history, in chronological order

\begin{tabular}{|l|l|l|l|l|l|}
\hline & British Empire & France & Saudi Kingdom & Iran & Turkey \\
\hline British Empire & - & Amity & Neutral & Amity & Neutral \\
\hline France & Amity & - & Neutral & Neutral & Neutral \\
\hline Saudi Kingdom & Neutral & Neutral & - & Neutral & Neutral \\
\hline Iran & Amity & Neutral & Neutral & - & Neutral \\
\hline Turkey & Neutral & Neutral & Neutral & Neutral & - \\
\hline
\end{tabular}

\begin{tabular}{|l|l|l|l|l|l|l|l|}
\hline & $\begin{array}{l}\text { Hashemite } \\
\text { Clan }\end{array}$ & $\begin{array}{l}\text { Arabian Gulf } \\
\text { Monarchies }\end{array}$ & $\begin{array}{l}\text { Republican } \\
\text { Arab Coun- } \\
\text { tries }\end{array}$ & Israel & $\begin{array}{l}\text { Pre-revolutio- } \\
\text { nary Iran }\end{array}$ & $\begin{array}{l}\text { Post-revolu- } \\
\text { tionary Iran }\end{array}$ & Turkey \\
\hline $\begin{array}{l}\text { Hashemite } \\
\text { Clan11 }\end{array}$ & - & $\begin{array}{l}\text { Enmity/ } \\
\text { Neutral }\end{array}$ & Enmity & $\begin{array}{l}\text { Enmity/ } \\
\text { Neutral }\end{array}$ & Neutral & Enmity & Neutral \\
\hline $\begin{array}{l}\text { Arabian Gulf } \\
\text { Monarchies }\end{array}$ & Enmity/ & - & $\begin{array}{l}\text { Enmity/ } \\
\text { Neutral }\end{array}$ & Enmity & Neutral & Enmity & Neutral \\
\hline $\begin{array}{l}\text { Republican } \\
\text { Arab Coun- } \\
\text { tries }\end{array}$ & Enmity & $\begin{array}{l}\text { Enmity/ } \\
\text { Neutral }\end{array}$ & - & Enmity & $\begin{array}{l}\text { Enmity/ } \\
\text { Neutral }\end{array}$ & $\begin{array}{l}\text { Enmity/ } \\
\text { Neutral }\end{array}$ & Enmity/ \\
\hline Israel & Enmity/ & Enmity & Enmity & - & Neutral & Enmity & $\begin{array}{l}\text { Neutral/ } \\
\text { Amity }\end{array}$ \\
\hline $\begin{array}{l}\text { Pre-revolutio- } \\
\text { nary Iran }\end{array}$ & Neutral & Neutral & $\begin{array}{l}\text { Enmity/ } \\
\text { Neutral }\end{array}$ & Neutral & - & - & Neutral \\
\hline $\begin{array}{l}\text { Post-revolu- } \\
\text { tionary Iran }\end{array}$ & Enmity & Enmity & $\begin{array}{l}\text { Enmity/ } \\
\text { Neutral }\end{array}$ & Enmity & - & - & Enmity \\
\hline Turkey & Neutral & Neutral & $\begin{array}{l}\text { Enmity/ } \\
\text { Neutral }\end{array}$ & $\begin{array}{l}\text { Neutral/ } \\
\text { Amity }\end{array}$ & Neutral & Enmity & - \\
\hline
\end{tabular}

\begin{tabular}{|l|l|l|l|l|l|l|l|l|l|l|}
\hline & $\begin{array}{l}\text { Tradi- } \\
\text { tional } \\
\text { Monar- } \\
\text { chies }\end{array}$ & Iran & Israel & Turkey & $\begin{array}{l}\text { Pre-2003 } \\
\text { Iraq }\end{array}$ & $\begin{array}{l}\text { Post- } \\
2003 \\
\text { Iraq }\end{array}$ & Egypt & Syria & Lebanon & Oatar \\
\hline $\begin{array}{l}\text { Tradi- } \\
\text { tional } \\
\begin{array}{l}\text { Monar- } \\
\text { chies }^{14}\end{array}\end{array}$ & - & Enmity & Neutral & $\begin{array}{l}\text { Neutral / } \\
\text { Enmity }\end{array}$ & Enmity & Neutral & Neutral & Enmity & Neutral & Enmity \\
\hline Iran & Enmity & - & Enmity & Neutral & Enmity & Neutral & $\begin{array}{l}\text { Enmity/ } \\
\text { Neutral }\end{array}$ & $\begin{array}{l}\text { Neutral/ } \\
\text { Amity }\end{array}$ & $\begin{array}{l}\text { Neutral/ } \\
\text { Amity }\end{array}$ & $\begin{array}{l}\text { Neutral/ } \\
\text { Amity }\end{array}$ \\
\hline
\end{tabular}




\begin{tabular}{|c|c|c|c|c|c|c|c|c|c|c|}
\hline Israel & Neutral & Enmity & - & Neutral & Enmity & Neutral & $\begin{array}{l}\text { Neutral/ } \\
\text { Amity }\end{array}$ & Enmity & $\begin{array}{l}\text { Neutral / } \\
\text { Enmity }\end{array}$ & Neutral \\
\hline Turkey & $\begin{array}{l}\text { Neutral / } \\
\text { Enmity }\end{array}$ & Neutral & Neutral & - & Enmity & Neutral & Neutral & Enmity & Neutral & $\begin{array}{l}\text { Neutral / } \\
\text { Amity }\end{array}$ \\
\hline $\begin{array}{l}\text { Pre-2003 } \\
\text { Iraq }\end{array}$ & Enmity & Enmity & Enmity & Enmity & - & - & Enmity & $\begin{array}{l}\text { Enmity / } \\
\text { Neutral }\end{array}$ & Neutral & $\begin{array}{l}\text { Neutral / } \\
\text { Enmity }\end{array}$ \\
\hline $\begin{array}{l}\text { Post- } \\
2003 \\
\text { Iraq }\end{array}$ & Neutral & Neutral & Neutral & Neutral & - & - & Neutral & Neutral & Neutral & Neutral \\
\hline Egypt & Neutral & $\begin{array}{l}\text { Enmity / } \\
\text { Neutral }\end{array}$ & $\begin{array}{l}\text { Neutral/ } \\
\text { Amity }\end{array}$ & Neutral & Enmity & Neutral & - & $\begin{array}{l}\text { Neutral / } \\
\text { Enmity }\end{array}$ & Neutral & $\begin{array}{l}\text { Neutral / } \\
\text { Enmity }\end{array}$ \\
\hline Syria & Enmity & $\begin{array}{l}\text { Neutral/ } \\
\text { Amity }\end{array}$ & Enmity & Enmity & $\begin{array}{l}\text { Enmity / } \\
\text { Neutral }\end{array}$ & Neutral & $\begin{array}{l}\text { Neutral / } \\
\text { Enmity }\end{array}$ & - & $\begin{array}{l}\text { Neutral / } \\
\text { Amity }\end{array}$ & $\begin{array}{l}\text { Neutral / } \\
\text { Enmity }\end{array}$ \\
\hline Lebanon & Neutral & $\begin{array}{l}\text { Neutral/ } \\
\text { Amity }\end{array}$ & $\begin{array}{l}\text { Neutral / } \\
\text { Enmity }\end{array}$ & Neutral & Neutral & Neutral & Neutral & $\begin{array}{l}\text { Neutral / } \\
\text { Amity }\end{array}$ & - & Neutral \\
\hline Qatar & Enmity & $\begin{array}{l}\text { Neutral / } \\
\text { Amity }\end{array}$ & Neutral & $\begin{array}{l}\text { Neutral / } \\
\text { Amity }\end{array}$ & $\begin{array}{l}\text { Neutral / } \\
\text { Enmity }\end{array}$ & Neutral & $\begin{array}{l}\text { Neutral / } \\
\text { Enmity }\end{array}$ & $\begin{array}{l}\text { Neutral / } \\
\text { Enmity }\end{array}$ & Neutral & - \\
\hline
\end{tabular}

References

ALLISON, Roy. Russia and Syria: explaining alignment with a regime in crisis. International Affairs, v. 89, n. 4, 2013.

ARRAF, Sarif. The Armed Conflict in Yemen: A Complicated Mosaic. The War Report. 2017. Geneva Academy.

BAKKER, Edwin. BOER, Leen. The evolution of Al-Qaedaism: Ideology, terrorists, and appeal. Hague: Netherlands Institute of International Relations Clingendael, 2007.

BARACSKAY, Daniel. The Evolutionary Path of Hamas: Examining the Role of Political Pragmatism in State Building and Activism. Terrorism and Political Violence, v. 27, n. 3, 2015.

BODDY-EVANS, Alistair. The Definition and Purpose of Political Institutions: How They Impact Law, Economy and Culture. Thought.Co, 2020. Available at: https://www.thoughtco. $\mathrm{com} /$ political-institutions-44026\#: :text=Political\%20institutions\%20are\%20the\%20organizations,provide\%20representation\%20for\%20the\%20population. Accessed: 01 dec. 2020.

BUZAN, Barry. Culture and international society. International Affairs, v. 86, n. 1, 2010.

BUZAN, B.. From International to World Society? English School Theory and he Social Structure of Globalisation. Cambridge: Cambridge University Press, 2004.

BUZAN, B., GONZALEZ-PELAEZ, Ana. International Society and the Middle East: English School Theory at the Regional Level. Hampshire: Palgrave MacMillan, 2009.

BUZAN, B., \& WÆVER, O.. Macrosecuritisation and Security Constellations: Reconsidering Scale in Securitization Theory. Review of International Studies, 35, 2009.

BUZAN, Barry. WÆVER, Ole. Regions and Powers: The Structure of International Security. New York: Cambridge University Press, 2003.

BUZAN, Barry. WÆVER, Ole. WILDE Jaap de. Security: A New Framework for Analysis. Colorado: Lynne Rienner, 1997.

CATHERWOOD, Christopher. A Brief History of Middle East. New York: Carroll and Graf Publishers, 2006.

CERIOLI, Luíza Gimenez. Roles and International Behaviour: Saudi-Iranian Rivalry in Bahrain's and Yemen's Arab Spring. Contexto Internacional, v. 40, n. 2, 2018.

CHARAP, Samuel; DRENNAN, John; NOËL, Pierre. Russia and China: A New Model of Great-Power Relations. Survival, v. 59, n. 1, 2017.

CHINA. China's National Defense in the New Era. The State Council of People's Republic of China. 2019.

CLEVELAND, William L. BUNTON, Martin. A History of the Modern Middle East. Philadelphia: Westview Press, 2009

DANFORTH, Nick. The Mosque, the Dam, and Erdogan's Widening Culture War: The Linked Fates of Two Cultural Heritage Sites in Turkey. Foreign Affairs. 2020.

DEVORE, Marc R. STÄHLI, Armin B. Explaining Hezbollah's Effectiveness: Internal and External Determinants of the Rise of Violent Non-State Actors. Terrorism and Political Violence, v. 27, n. $2,2015$. 
EWERS, Elisa Catalano. Before the House Foreign Affairs Committee, Sub-Committee on the Middle East, North Africa, and International Terrorism: Hearing on Assessing U.S. Policy Priorities in the Middle East. Center for a New American Security. 2019.

FAHY, John. International Relations and Faith-based Diplomacy: The Case of Qatar. The Review of Faith \& International Affairs, v. 16, n. 3, 2018.

GORDON, David F; TONG, Haoyu; ANDERSON, Tabatha. Beyond the Myths - Towards a Realistic Assessment of China's Belt and Road Initiative: The Development-Finance Dimension. International Institute of Strategic Studies.

HALLIDAY, Fred. The Middle East in International Relations: Power, Politics and Ideology. Cambridge: Cambridge University Press, 2005.

IISS. Iran's Networks of Influence in the Middle East. London: International Institute of Strategic Studies, 2019.

IISS. Qatar and its neighbours. Strategic Comments, v. 25, n. 2, 2019.

KAMRAVA, Mehran. The Modern Middle East A Political History since the First World War. Berkeley: University of California Press, 2011.

KHALID, Rashid. The Palestinians and 1948: the underlying causes of failure. In: ROGAN, Eugene L. SHLAIM, Avi. The War for Palestine. Cambridge: Cambridge University Press, 2008.

KHLEBNIKOV, Alexey. Iran, Russia, and the impact of US sanctions. Middle East Institute. 2019.

LASMAR, Jorge M. Managing great powers in the post-Cold War world: old rules new game? The case of the global war on terror, Cambridge Review of International Affairs, v. 28, n. 3, 2015.

LIKA, Idlir. The Quest for Security: Soviet Union's Demands from Turkey, 1945 - 1946. 2015. $101 \mathrm{f}$. Department of International Relations, İhsan Doğramac1 Bilkent University, Ankara, 2015.

LIN, Zhimin. Xi Jinping’s ‘Major Country Diplomacy’: The Impacts of China’s Growing Capacity. Journal of Contemporary China, v. 28, n. 115, p. 31-46.

MAHENDRARAJAH, Shivan. Saudi Arabia, Wahhabism, and the Taliban of Afghanistan: 'Puritanical reform' as a 'revolutionary war' program. Small Wars \& Insurgencies, v. 26, n. 3, 2015.

MASCITELLI, Bruno. Erdogan's Turkey: The Authoritarian Alternative to Populism. Australian Institute of International Affairs. 2019.

MASSOULIÉ, François. Os Conflitos do Oriente Médio. São Paulo: Editora Ática, 1996.

MATHER, Yassamine. The Fall of the Ottoman Empire and Current Conflict in the Middle East. Critique, v. 42, n. 3, 2014.

MEARSHEIMER, John J. The Great Delusion: Liberal Dreams and International Realities. New Haven: Yale University Press, 2018.

MOKHTARI, Fariborz. Countering Terrorism: Could Hezbollah and Hamas Show the Way?. Contemporary Security Policy, v. 27, n. 3, 2006.

OUTZEN, Richard. From Crisis to Cooperation Turkey's Relations with Washington and NATO. The Washington Institute for Near East Policy. 2012.

PALABIYIK, Mustafa Serdar. The Emergence of the Idea of 'International Law' in the Ottoman Empire before the Treaty of Paris (1856). Middle Eastern Studies, v. 50, n. 2, 2014.

PIEPER, Moritz. 'Rising Power' Status and the Evolution of International Order: Conceptualising Russia’s Syria Policies. Europe-Asia Studies, v. 71, n. 3, 2019.

PINTO, Maria do Céu de Pinho Ferreira. Mapping the Obama administration's response to the Arab Spring. Revista Brasileira de Política Internacional, v. 55, n. 2, 2012.

ROGAN, Eugene L. SHLAIM, Avi. The War for Palestine. Cambridge: Cambridge University Press, 2008

ROGERS, Paul. Lost cause: consequences and implications of the war on terror. Critical Studies on Terrorism, v. 6, n. 1, 2013.

ROMERO, Juan. Arab Nationalism and the Arab Union of 1958. British Journal of Middle Eastern Studies, v. 2, n. 2, 2015.

SANDHOLTZ, W.; STILES, K. International Norms and Cycles of Change. New York: Oxford University Press. 2008

SCHMID, Alez P. Root Causes of Terrorism: Some Conceptual Notes, a Set of Indicators, and a Model. Democracy and Security, v. 1, n. 2, 2005. 
SHLAIM, Avi. Israel and the Arab coalition in 1948. In: ROGAN, Eugene L. SHLAIM, Avi. The War for Palestine. Cambridge: Cambridge University Press, 2008.

SINGH, Rashmi. Hamas and Suicide Terrorism: Multi-Causual and Multi-Level Approaches. London: Routledge, 2011.

TZEPRIN, Atina. JOZIC, Jugoslav. LAMBARÉ, Henry. The Middle East Cold War: Iran-Saudi Arabia and the Way Ahead. Croatian Political Science Review, v. 52, n. 4, 2015.

United Nations Security Council Resolution 662.

United Nations Security Council Resolution 674

United Nations Security Council Resolution 687

United Nations Security Council Resolution 692

US DEPARTMENT OF STATE. Foreign Terrorist Organizations. Washington, 2020.

WELSH, Jennifer M. Empire and Fragmentation in DUNNE, Tim; REUS-SMIT, Christian. The Globalization of International Society, Oxford: Oxford University Press, 2017.

WHITE HOUSE. Peace to Prosperity: A Vision to Improve the Lives of the Palestinian and Israeli People. Washington: White House. 2020.

ZÜRCHER, Erik Jan. Young Turk Governance in the Ottoman Empire during the First World War. Middle Eastern Studies, v. 55, n. 6), 2019. 